\title{
Produções digitais nos 50 anos do Golpe de 1964: especiais multimídias em sites jornalísticos brasileiros
}

Digital productions in the 50 years of the 1964 Coup: specials multimedia in Brazilian journalistic sites

Producciones digitales en los 50 años del Golpe de 1964: especiales multimedia en sitios periodísticos brasileños

DOI: https://doi.org/10.1590/1809-5844202114

\author{
Allysson Viana Martins ${ }^{1}$ \\ http://orcid.org/0000-0001-7805-6512 \\ ${ }^{1}$ (Universidade Federal de Rondônia, Departamento de Jornalismo. Porto Velho - RO, Brasil).
}

\section{Resumo}

Os jornais representam uma inscrição da realidade histórica e da memória coletiva de determinada época. Este artigo discute o papel das produções jornalísticas digitais na constituição e na estabilização da história do Golpe de 1964, em seus 50 anos, uma vez que as digitalizações da memória e do jornalismo trazem novas configurações para ambos. Averiguam-se as produções dos sites jornalísticos de dois veículos relevantes no período do golpe e de dois nativos digitais. Os especiais concebem, com narrativa padrão, o golpe e a ditadura militar como algo negativo e pernicioso para a história do país, com alguma complacência aos golpistas por G1 e O Estado de S. Paulo; a exceção deste de São Paulo, os outros três especiais trazem um tom didático e histórico, com cronologia, fontes e referências.

Palavras-chave: Jornalismo digital. Golpe de 1964. História. Memória. Especiais multimídias.

\begin{abstract}
The newspapers represent an inscription of the historical reality and of the collective memory of a certain space and time. This article discusses the role of digital journalistic productions in the constitution and stabilization of the history of the Coup of 1964, in its 50 years, since the digitalization of memories and of journalism bring new configurations for both. The productions of the journalistic sites of two relevant vehicles in the period of the coup and of two digital natives are analyzed. The productions conceive, with standard narrative, the coup and military dictatorship as something negative and pernicious for the history of the country, with some complacency to the coupists by G1 and O Estado de S. Paulo; the exception of this one of São Paulo, the other three specials bring a didactic and historical tone, with chronology, sources and references.
\end{abstract}

Keywords: Digital journalism. 1964 Coup. History. Memory. Specials multimedia. 


\section{Resumen}

Los periódicos representan una inscripción de la realidad histórica y de la memoria colectiva de determinada época. Este texto discute el papel de las producciones periodísticas digitales en la constitución y la estabilización de la historia del Golpe de 1964, en sus 50 años, una vez que las digitalizaciones de la memoria y del periodismo traen nuevas configuraciones para ambos. Se verifican las producciones de los sitios periodísticos de dos vehículos relevantes en el período del golpe y de dos nativos digitales. Los especiales conciben, con narrativa estándar, el golpe y la dictadura militar como algo negativo y pernicioso para la historia del país, con alguna complacencia a los golpistas por G1 y de O Estado de São Paulo; la excepción de éste de São Paulo, los otros tres especiales traen un tono didáctico e histórico, con cronología, fuentes y referencias.

Palabras clave: Periodismo digital. Golpe de 1964. Historia. Memoria. Especiales multimedia.

\section{Introdução}

O jornalismo é pensado como primeiro rascunho da história e da memória coletiva (ZELIZER, 2008, PALACIOS, 2009, 2014), uma vez que seus profissionais trabalham em organizações que, cotidianamente, registram e difundem os acontecimentos da atualidade, apresentando aquilo que consideram relevantes naquele momento para a sociedade. $\mathrm{O}$ passado, através da história e da memória, não é evidenciado apenas desta maneira, mas ainda para tratar dos eventos atuais, para que se tenha uma compreensão ampla e profunda dos acontecimentos, em sua complexidade. Os historiadores, sobretudo nas sociedades em que os meios de comunicação possuem funções centrais, passam a considerar a mídia, o jornal e as suas produções como fonte histórica e memorial de um espaço e um tempo determinado. Esses profissionais não desconsideram, evidentemente, as intencionalidades de quando foram desenvolvidos esses produtos, uma vez que os agentes desejam cristalizações e estabilizações de suas perspectivas.

Na modalidade mais recente do jornalismo, isto é, na sua versão digital, (ciber)espaço onde a memória se apresenta em um novo paradigma, o passado ganha mais atenção no sistema produtivo da informação, conforme Hoskins (2009, 2011a, 2011b), Neiger, Meyers e Zandberg (2011) e Reading (2011). Aqui, ocorre uma espécie de passagem da memória coletiva para a conectada, ou midiática, uma vez que a associação entre mídia e memória se modifica ao se considerar as novas maneiras de recordação, silenciamento e esquecimento em um sistema digital e global. As mudanças infraestruturais das memórias em arquivo digital são potencializadas para uma construção que possibilita a aquisição de novas especificidades e acúmulos de conteúdos, uma espécie de memória em fluxo (memory on-the-fly).

As materialidades tradicionais das memórias são confrontadas agora por elementos de fluidez, reprodutibilidade e transferência, situando novas temporalidades e dinâmicas em uma indexação e organização permanentes, em detrimento do ideal precedente do arquivo, em determinada medida, estático. Esses documentos digitalizados passam por uma lógica 
de cauda longa ${ }^{1}$ do passado, de colaboração para a construção da memória coletiva e de dinâmica relacional entre as mídias mais recentes e antigas, auxiliando para a caracterização de uma nova ecologia midiática e da memória.

A ligação entre a memória e o jornalismo está imbricada já na produção jornalística, em sua prática e em seu produto; mesmo que o jornalismo enfatize o atual, relaciona-se adequadamente com a memória. Ainda que a memória se dedique ao passado, ela é um presente singular e concreto com vistas ao que já não existe. O jornalismo transforma essa atualidade no primeiro registro do passado. O arquivamento e indexação diária dessa produção jornalística do cotidiano transforma os seus produtos em memórias coletivas, e midiáticas, de um determinado espaço e tempo. As produções jornalísticas, sobretudo, passam a ser documentos de um período histórico, uma rede complexa de recordações e esquecimentos desses tempos que já não estão mais presentes (MACHADO, 2001, ZELIZER, 2008, PALACIOS, 2009, 2014, SÁ, 2011).

Essa perspectiva aparece de maneira tão predominante que a memória é um dos aspectos do jornalismo digital mais enfatizados, em relação às produções jornalísticas em outros suportes. Ela é definida como múltipla - devido à possibilidade de acesso aos diversos formatos midiáticos -, instantânea - acessível pelo produtor e pelo leitor rapidamente através dos links - e cumulativa - graças ao seu baixo custo de arquivamento (PALACIOS, 2002, 2003, 2008, 2014). Se o jornalismo é, por vezes, percebido como efêmero, com curto prazo de validade do seu material, os conteúdos agora estão possivelmente em um presente contínuo. O jornalismo trabalha a memória individual, coletiva ou mesmo midiática de modo cada vez mais estratégico, ao trazer as informações e os documentos passados em uma nova estruturação produtiva. A mídia adquire essa posição de relevância porque as memórias são transmitidas através dela, agindo como o primeiro veículo para transmissão de conhecimento e percepções sobre o passado e o presente. Se a era da comunicação de massa foi a era da memória coletiva, conceitualmente e experimentalmente, hoje se vive em uma época de memória conectada e digital, não apenas coletiva.

A memória midiática contribui para uma organização individual, social e até do tempo, com sua grade de programação, e enfatiza, de maneira multidimensional, o modo como a mídia opera como agente de memória, a cultura em que os processos acontecem e as inter-relações entre mídia e outras atividades e instituições sociais (NUNES, 2001, NEIGER; MEYERS; ZANDBERG, 2011). Os meios de comunicação se tornam ainda construtores das memórias, não apenas seus difusores. Eles possuem, nas sociedades ocidentais contemporâneas, uma função essencial na produção e na manutenção da história e das memórias - até individuais -, sendo, possivelmente, o lugar de memória mais legitimado e prestigiado.

1 A cauda longa é um processo de segmentação específico de público. Desenvolvida por Anderson (2006), volta-se, inicialmente, para uma lógica comercial na qual são vendidos muitos itens distintos e específicos em pequena escala, no lugar de poucos produtos em grande quantidade. 
Os meios de comunicação, especificamente o jornalismo, já contribuíram, por exemplo, para a criação de um ambiente propício para a deposição do presidente em 1964 (KOSHIYAMA, 1988, FERREIRA, 2003, FICO, 2004, 2005, DELGADO, 2010, CARDOSO, 2012, FERREIRA; GOMES, 2014, MACHADO, 2014, REIS; RIDENTI; MOTTA, 2014, REIS, 2014, RIDENTI, 2014). Em uma investigação minuciosa dos editoriais e dos textos opinativos dos grandes jornais no período de 1961 até 1964, Machado (2014) defende que o Golpe de 1964 não pode ser expressado como militar ou civil-militar, mas como midiáticocivil-militar, uma vez que, sem o trabalho da imprensa, a deposição do presidente não teria legitimidade. Esse ambiente propício foi construído diariamente ao se falar à população o que pensar sobre Jango e suas propostas, enfatizando tudo que havia de negativo e até inventando o que não existia, com jornalistas chegando ao ponto de chamá-lo de bêbado para desqualificá-lo. A mídia, de modo geral, acusava João Goulart e seus aliados de terem exagerado na propaganda e provocado os militares.

Em 18 de novembro de 2011, a presidenta Dilma Rousseff sancionou a Lei $n^{\circ} 12.528$, para a criação da Comissão Nacional da Verdade, que investigou e tornou públicas as violações contra os direitos humanos de 1946 e 1988 cometidas pelos agentes do Estado no Brasil. Esses processos de reconhecimento, revisão e reparação da história do golpe e da ditadura militar, mesmo que sejam manifestados ainda durante o período de repressão, são intensificados com a Lei, que se tornou um agente nas guerras de memórias. Foi nesse contexto favorável de retração histórica que os jornais produziram seus especiais.

Hoje, mais de 50 anos depois, a mídia possui ainda mais relevância nas sociedades contemporâneas, bem como as memórias - com novas especificidades e procedimentos de recorrência devido à digitalização. Com isso em vista, uma investigação sobre a efeméride do cinquentenário do golpe nesse mais recente (ciber)espaço midiático se apresenta com uma conjunção de fatores propícios, sobretudo tendo como estudo de caso os especiais jornalísticos digitais. A perspectiva das guerras de memórias (LINDENBERG, 1994, STORA, 2007, BLANCHARD; VEYRAT-MASSON, 2008a, 2008b), em que o passado é sempre usado politicamente, especialmente na mídia, permite avaliar os especiais multimídias a partir da descrição e da articulação de três instâncias: atores - pessoas ou tecnologias envolvidas; territórios de batalha - levantamento de questões e contradições; e armas - como são apresentados os assuntos pelos atores, legitimando ou não o seu discurso, contribuindo ou não para a estabilização das suas perspectivas.

Para isso, selecionamos as produções de sites jornalísticos de veículos já relevantes no período do golpe e da ditadura, como Folha de S.Paulo e O Estado de S. Paulo, ambos apoiadores do golpe de 1964, e dois nativos digitais, surgidos já nos anos de 2000: portal G1, do maior grupo midiático do país, que apoiou não só o golpe como a ditadura através dos seus outros veículos, e o Último Segundo, setor jornalístico do portal iG, um dos principais do país na atualidade, mas sem tradição no ramo da informação, ainda que tente homenagear, ao menos em nome, o jornal Última Hora, criado por Samuel Wainer e considerado de esquerda, especialmente nos apoios a Vargas e, depois, Goulart. Desta maneira, o objetivo deste artigo 
é avaliar o papel das produções jornalísticas digitais na constituição e na estabilização da história do Golpe de 1964, através dos especiais multimídias sobre a efeméride dos seus 50 anos, uma vez que as digitalizações da memória e do jornalismo trazem novas configurações para ambos.

\section{Folha de S.Paulo}

A narrativa multimídia “Tudo sobre a ditadura militar” inicia com um texto grifado ao descrever nossa recente democracia como "incapaz de pacificar as controvérsias do período” e com a apresentação dos ex-presidentes envolvidos diretamente no combate à ditadura, como Fernando Henrique Cardoso, Luiz Inácio ‘Lula’ da Silva e Dilma Rousseff, esquecendo-se de José Sarney, primeiro presidente após a ditadura e que tinha relação direta com o regime autoritário dos militares, inclusive, sendo eleito pela ARENA, partido de sustenção do governo. Com uma equipe de praticamente 30 pessoas, a reportagem trata os 21 anos de repressão através de um menu com oito seções, além de um expediente e de uma lista extensa de fontes e referências - com indicação dos livros e links para os áudios das entrevistas e até transcrições em inglês. A navegação ocorre de duas maneiras: verticalmente, em que se passa obrigatoriamente pelas oito seções, - sendo que, ao final de cada uma, deve-se clicar em uma seta para seguir até a subsequente - ou pelo menu, no canto superior direito, em que se pode aceder diretamente à seção, a saber: Introdução; A crise; A ditadura; A economia; A abertura; O acerto de contas; E se...; Artigos.

A ideia de golpe e ditadura aparece como a história que deve ser contada, em que se deve confiar, durante todo o especial, ainda que em raras partes haja complacência com alguns dos argumentos dos militares, especialmente nos textos opinativos das últimas duas seções, “E se...” e “Artigos”. Os únicos momentos em que o golpe e a ditadura aparecem como positivos são nos depoimentos em vídeo de militares e de ex-políticos que os apoiavam, publicizando as perspectivas dessas fontes (ver Figura 1). Contudo, a ênfase nas memórias individuais ${ }^{2}$, ou seja, dos depoentes, pendiam mais para aqueles que eram contrários ao regime autoritário, uma vez que, nas duas ocasiões, em vídeo, praticamente $70 \%$ dos depoimentos eram destinados a essa perspectiva.

2 A memória individual é aqui expressa a partir do armazenamento e da recuperação de ordem privada, a nível neural e fisiológico (SILVA, 2002, ROEDIGER III; WERTSCH, 2008, BOURDON, 2011, NEIGER; MEYERS; ZANDBERG, 2011). Desta forma, não se refere às formas pessoais de externalização, como diários e fotos (SANTAELLA, 2003, 2007, RADSTONE, 2008, PALACIOS, 2009, 2014). 
Figura 1 - Mosaico dos depoimentos em vídeos no final da "Introdução"

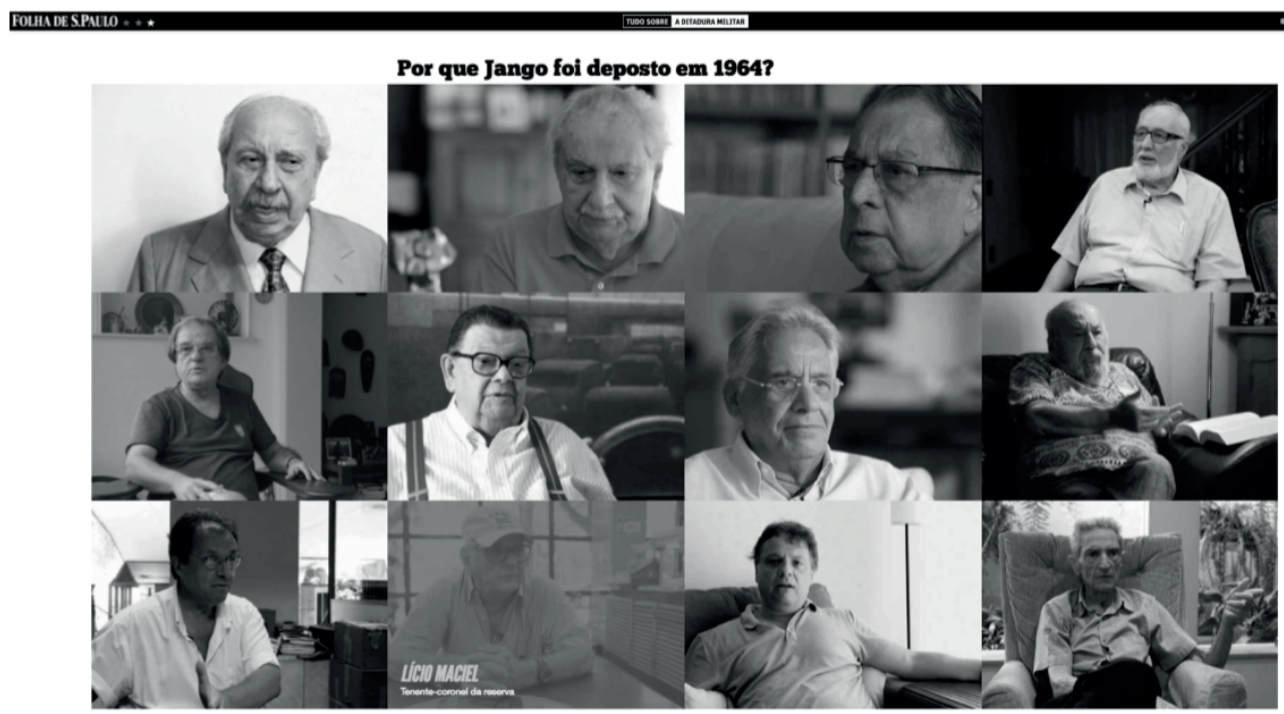

Fonte: Folha.com.

O conhecimento das versões da história é obtido, normalmente, a partir da visão dos heróis, dos reis, dos catequizadores, dos autorizados, ou seja, dos vencedores, ainda que essa perspectiva não possa ser verificada em sua completude no período da ditadura militar brasileira (ROLLEMBERG, 2006). Os militares acreditam que, após a derrota da esquerda, os militantes se esforçaram para vencer no campo das letras o que perderam na arma isto é, na propagação das memórias e na constituição historiográfica da ditadura militar. Le Goff (2013 [1988]) diz que os vencidos reagem às "histórias racionais" dos vencedores através de uma "tradição como meio de recusa", de uma "história lenta”, isto é, de uma forma de oposição e resistência. Os conflitos mnemônicos, interesses e ideologias colidem para se transmitir uma mensagem para as próximas gerações, verdadeira ou não. A intenção é cristalizar suas memórias ao torná-las oficiais, a única história autêntica e possível. Na visão de Blanchard e Veyrat-Masson (2008b), a memória deve ser encarada como uma arma política que visa à fixação das perspectivas de mundo e ideológicas.

A narrativa de praticamente todo o especial é distinta daquela do padrão jornalístico, com hierarquia da pirâmide invertida ${ }^{3}$ e extensa citação das fontes entrevistadas; possui, na verdade, uma estrutura cronológica e quase nenhuma citação - restrita aos vídeos com curtos depoimentos, único espaço em que a memória individual prevalece. Como no especial há pouca citação, direta ou indireta, uma das suas seções é destinada às "Fontes e Referências” utilizadas para a sua produção, com um caráter mais histórico e didático. Entre

3 A técnica jornalística da pirâmide invertida consiste em distribuir as informações em ordem hierárquica decrescente de relevância, com o primordial aparecendo primeiro. Ela permite que o conteúdo seja retirado da produção com mais facilidade e que o público tenha contato imediato com as informações mais importantes (CANAVILHAS, 2006, 2014, FRANCO, 2008, SCHUDSON, 2010). 
as referências, temos os livros de Elio Gaspari, Daniel Aarão Reis, Marcelo Ridenti, entre outros pesquisadores relevantes da área, além de uma obra desenvolvida pela Comissão Especial sobre Mortos e Desaparecidos Políticos da Secretaria Especial dos Direitos Humanos da Presidência da República. Entre as fontes, temos ainda as conversas na íntegra e no original em inglês dos presidentes estadunidenses John Kennedy e Lyndon Johnson com seus assessores na Casa Branca.

A produção histórica do próprio jornal praticamente não foi utilizada, citada apenas em um artigo de opinião, que explanou sobre a atuação dos principais meios de comunicação durante o golpe e os primeiros anos da ditadura. Cabe salientar que não foram disponibilizadas as publicações da Folha de S.Paulo nem dos outros veículos citados neste texto, ou seja, a digitalização desses materiais do período da ditadura militar - já encontrados nas seções de acervo ou arquivos nos sites dos grandes jornais e grupos de comunicação do país - são inexistentes no especial da Folha. O jornal apoiou o Golpe de 1964 e reforçou a sua colaboração com os militares imediatamente após a promulgação do AI-5, ao demitir diversos jornalistas; sendo um dos principais movimentos para o veículo praticamente não sofrer censuras e sanções da ditadura. O grupo ainda ficou marcado pelas suas caminhonetes incendiadas em 1971, por terem sido emprestadas aos militares para carregarem civis e militantes para prisão, onde eram interrogados, torturados e assassinados. O proprietário, Otávio Frias de Oliveira, em 22 de setembro de 1971, defende a ditadura de sete anos e nega não só a existência de torturas e de assassinatos, mas de presos políticos (DIAS, 2014, 2015).

A produção jornalística histórica sobre o golpe e o regime autoritário instaurado pelos militares aparece, na verdade, em apenas um vídeo, com uma reportagem da TV Cultura sobre as Diretas Já. Outras produções históricas neste formato são disponibilizadas, contudo, mais próximas de um material de assessoria, uma vez que partiam do governo militar. O Instituto de Pesquisas e Estudos Sociais (IPES) e o Instituto Brasileiro de Ação Democrática (IBAD) faziam uma campanha e propaganda político-ideológica com apoio até no Congresso Nacional, além de ajuda material e financeira para passeatas, manifestações e produções visuais e audiovisuais.

O especial conta com uma grande variedade de formatos midiáticos, como é próprio das narrativas multimídias ${ }^{4}$ (BARBOSA; NORMANDE; ALMEIDA, 2014). As mais de trinta fotos, por exemplo, representam sempre situações históricas, como posse de presidentes militares e do presidente Tancredo Neves, porém, principalmente, de atrocidades e crimes cometidos pelos militares, expondo a crueldade nas perseguições, torturas e mortes de Carlos Marighella, Carlos Lamarca, Vladimir Herzog, guerrilheiros no Araguaia, entre outros. Foram publicadas ainda imagens relevantes de acontecimentos, como o carro-bomba durante show no Riocentro, mostrando "até onde a direita militar estava disposta a chegar

4 As narrativas multimídia são entendidas como as melhores produções do jornalismo digital, pois não só utilizam os formatos midiáticos de forma complementar, mas estruturam todo o seu especial combinando, principalmente, interação, multimídia e hipermídia (BARBOSA; NORMANDE; ALMEIDA, 2014, NORMANDE, 2014). 
para frear o processo de abertura”, pois o explosivo foi "plantado pelos militares”, e de movimentos, como o Comício das Reformas, a Marcha da Família com Deus pela Liberdade e as Diretas Já. As fotos têm como fontes, de modo geral, os acervos dos Grupos Abril, Folha e Globo, além dos jornais Jornal do Brasil e Última Hora.

Todos os quatro áudios no especial são históricos, desde a campanha dos militares na rádio até os discursos e as declarações de políticos e militares em momentos relevantes, como Auro de Moura Andrade, senador e presidente do Congresso, Jarbas Passarinho, Ministro do Trabalho, e Ernesto Geisel, militar e ex-presidente. O especial conta ainda com praticamente cinquenta vídeos, sendo aproximadamente dez de cunho histórico registros e produções da ditadura, realizadas pelo governo ou pelos opositores, além de uma reportagem em vídeo da TV Cultura sobre as Diretas Já - e o restante composto por depoimentos atuais de intelectuais, jornalistas, políticos, militantes e militares, falando sobre os motivos que levaram Jango a ser deposto e as principais lembranças dos depoentes sobre a ditadura militar. Ao contrário do início dos anos 1960, quando o jornalismo desenvolveu um ambiente em que não só era inevitável, mas também necessária, a deposição do presidente João Goulart (KOSHIYAMA, 1988, FERREIRA, 2003, FICO, 2004, 2005, DELGADO, 2010, FERREIRA; GOMES, 2014, MACHADO, 2014, REIS; RIDENTI; MOTTA, 2014, REIS, 2014, RIDENTI, 2014), os ataques a Jango são agora considerados exagerados ou mentirosos.

O especial contou, ainda, com mais de 20 infográficos, dos quais três se debruçavam sobre os Atos Institucionais 1, 2 e 5 e quase metade sobre questões econômicas, na seção específica para falar sobre o momento que foi “Do milagre à bancarrota” (ver Figura 2). Os mais complexos e interativos, por sua vez, trataram sobre as atrocidades e os crimes contra os direitos humanos cometidos pelos militares durante a ditadura: "A escala da repressão”, “Cinco tons de cinza”, “Terror à direita”, “Hora da reparação”, “Donos do porão” e "Mortos na contramão”, este com informações sobre todos os 356 considerados oficialmente como mortos e desaparecidos. As fontes principais para essas produções foram a publicação conjunta da Câmara dos Deputados, do Projeto Brasil: Nunca Mais e da Secretaria Especial dos Direitos Humanos da Presidência da República, além do IBGE, Banco Central, Fundação Getúlio Vargas, IpeaData e das obras de Maria Gil Kinzo, do Senado Federal e do Tribunal Superior Eleitoral. 
Figura 2 - “Do milagre à bancarrota” desmistifica a ideia de milagre econômico

\section{Do milagre à bancarrota}

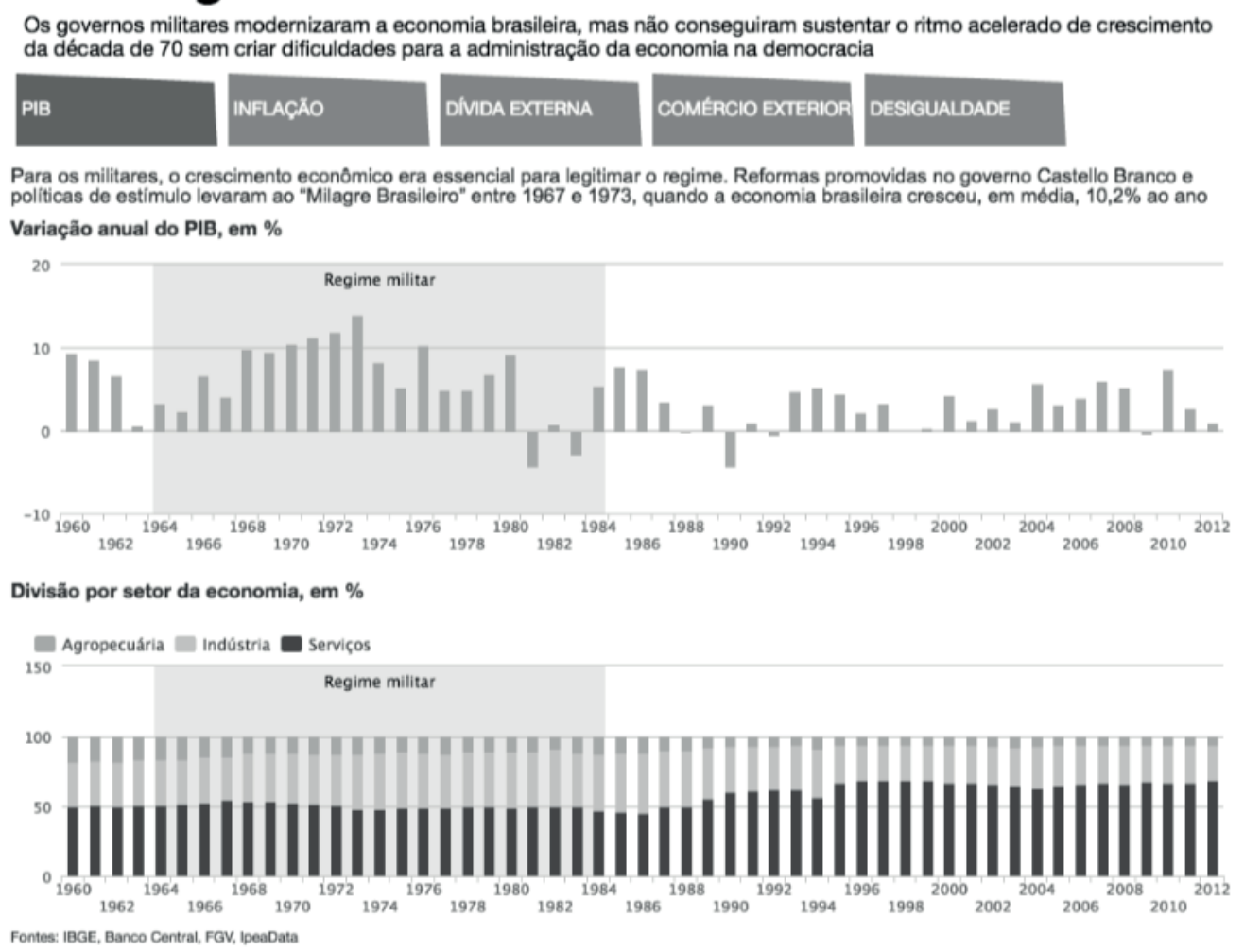

Fonte: Folha.com.

\section{O Estado de S. Paulo}

O especial, denominado “Tudo Sobre 1964”, traz sete matérias em destaque no slide e mais dez produções abaixo, todas com chamada acompanhada de imagem, em uma página padrão dedicada ao cinquentenário do golpe. Das 17 produções, apenas duas não trazem no destaque imagens históricas, sendo matérias com as visões dos ex-presidentes José Sarney e Fernando Henrique Cardoso sobre a ditadura militar e suas influências na atualidade. As seis produções ao final de página estão subdivididas em dois temas: "Censura à imprensa” e “Tortura”. Apenas uma ficou de fora de nossa análise, pois era a reprodução do documentário $O$ dia que durou 21 anos.

A ideia de golpe e ditadura está bastante conformada nas publicações, ainda que em diversas vezes as produções sejam condescendentes com alguns dos argumentos dos 
militares, especialmente sobre os “perigosos” Jango e Brizola e uma possível ameaça comunista. Semelhante ao que aconteceu na década de 1960, o jornal ainda traz a ideia de que João Goulart poderia dar um golpe comunista. Embora hoje considerada sem base, essa perspectiva foi endossada pelo jornal no passado. Cada produção visava à publicização das versões das fontes entrevistadas, com ênfase estritamente nas memórias dos depoentes - a favor ou contrário à ação dos militares -, ou do escritor do texto, no caso daqueles nos moldes dos artigos de opinião. Todavia, está em evidência em toda a produção o apoio dos Estados Unidos ao golpe e aos militares, citado em muitas ocasiões distintas e com produções para esta finalidade. Os EUA contribuíram financeiramente com os adversários do presidente para oposição no Congresso Nacional (FERREIRA; GOMES, 2014, REIS; RIDENTI; MOTTA, 2014).

O primeiro texto possui um aspecto mais histórico e didático, com uma narrativa cronológica - diferente do modelo jornalístico com hierarquia da pirâmide invertida - e quase nenhuma citação, semelhante às narrativas multimídias, mesmo que o Estadão não tenha realizado um especial deste tipo. Isso fica evidente posteriormente, quando se acessam as outras produções - a maioria em formato de reportagem, com estrutura hierárquica de um texto jornalístico padrão, ou de artigo de opinião -, com as fontes sendo citadas como base e fundamento do jornalista, desde pesquisadores até indivíduos que vivenciaram o golpe e a ditadura militar, especialmente políticos - com destaque a dois ex-presidentes, José Sarney e Fernando Henrique Cardoso - e ex-militares. A memória individual prevaleceu como principal embasamento para as publicações, ainda que livros, leis, documentos oficiais e especialistas estejam presentes.

Os formatos midiáticos do especial traziam, a partir da digitalização, conteúdos históricos principalmente do próprio Grupo Estado. O único infográfico conta a história do golpe e da ditadura a partir de uma autorreferência das produções históricas de $O$ Estado de S. Paulo (ver Figura 3). Os vídeos, por sua vez, são produções atuais, com depoimentos de ex-militares e ex-presidentes, com apenas 30 segundos iniciais de filmagens do golpe e da declaração de vacância da Presidência da República. Enquanto os áudios disponibilizados são de momentos históricos advindos da Rádio Jornal do Brasil, especialmente da primeira década da ditadura militar, as fotografias são quase todas históricas do próprio acervo do Grupo Estado ou de acervos pessoais já pertencentes ao Arquivo Estadão. Essas fotos, contudo, estavam não nas produções, mas nas chamadas na página principal, com poucas atuais, como aquelas para as entrevistas com os ex-presidentes Sarney e FHC e outra para uma matéria com dados recentes sobre as torturas, com indivíduos se manifestando em frente a um local não identificado. 
Figura 3 - Infográfico com poema substituindo matéria censurada em O Estado de S. Paulo

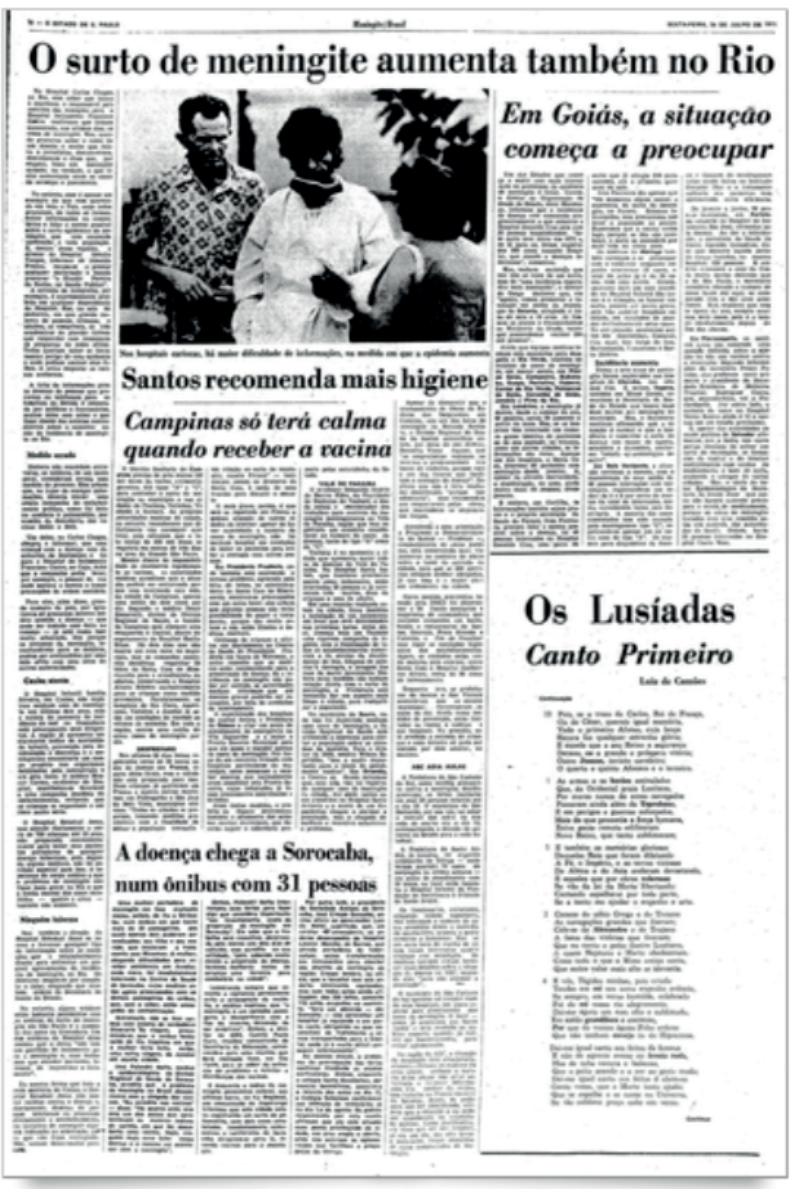

\section{7 de Abril de 1973 \\ Jornal censurado}

Censura prévia a periódicos.

Recusando a auto-censura, O Estado passa a ter censores na sede do jornal e publica versos de Camões no lugar das notícias proibidas.

th Leia mais no Acervo Estadão

Fonte: Estadão.

A perspectiva histórica aparece até em formato textual, ao se revelar diálogos do período da ditadura, sobretudo nas duas últimas seções: “Censura à imprensa" e "Tortura". Essas reproduções buscavam transportar o leitor às violências cometidas pelos militares e pelos seus apoiadores contra as vítimas fontes do veículo - como os militares torturados e os próprios proprietários do Grupo Estado -, a exemplo do diálogo entre agentes militares que serviam ao DOI-CODI voluntariamente. A violência perpetrada pelos agentes repressivos do Estado ganhou uma atenção particular neste especial. Embora o jornal apoiasse o golpe, alegando que o presidente não tinha autoridade suficiente para comandar o país (MACHADO, 2014), ao perceber que a intervenção militar não era transitória, voltou-se contra a ditadura militar e passou a denunciar crimes como desaparecimento, tortura e assassinato, sofrendo censura por parte do regime autoritário. 


\section{Portal G1}

Os "50 anos do golpe militar de 1964" é um especial multimídia interativo, com três grandes narrativas. A primeira sobre o "Brasil Pré-64", seguida de uma explicação d“O Golpe em 33 Dias" - mais longo e como aba central e padrão ao se abrir o especial - e o "Quem é Quem" dos envolvidos com a ditadura. Ao todo, nove profissionais se dedicaram para edição, design, desenvolvimento e pesquisas do especial, que teve como fontes: Centro de Pesquisa e Documentação de História Contemporânea do Brasil - CPDOC da Fundação Getúlio Vargas e o Arquivo Nacional, além dos livros "A democracia nas urnas", de Antonio Lavareda, "Democracia ou reformas", de Argelina Figueiredo, e "O jornalismo e o Golpe de 1964: 50 anos depois”, de Luiz Antônio Dias.

A concepção de golpe e ditadura permeia a maior parte da narrativa multimídia, com transigência, em diversos momentos, com os militares, como no caso citado da posse de João Goulart após a renúncia de Jânio Quadros. Essas perspectivas apagam que Jango e Brizola, seu apoiador e cunhado, tiveram de pressionar o governo e os militares para que 0 vice assumisse. Ou seja, não é como se os futuros agentes repressores do estado tivessem resolvido ser legalistas para manter a harmonia do país e do Congresso. A produção foi bastante complacente todas as vezes que poderiam culpar Jango, com seu viés "esquerdista" e "comunista", como se o golpe fosse justificado nessas situações. Como foi colocado, o presidente tentou "radicalizar" a política ao tentar aprovar as "reformas de base na "lei ou na marra”, desta forma, "suas medidas acabaram servindo de munição para os adversários, que planejavam o golpe”. Essas perspectivas vão ao encontro do que aconteceu no início da década de 1960, hoje considerado sem fundamento, quando os jornais endossaram o golpe.

Figura 4 - Abertura da parte principal do especial com "O golpe em 33 dias”

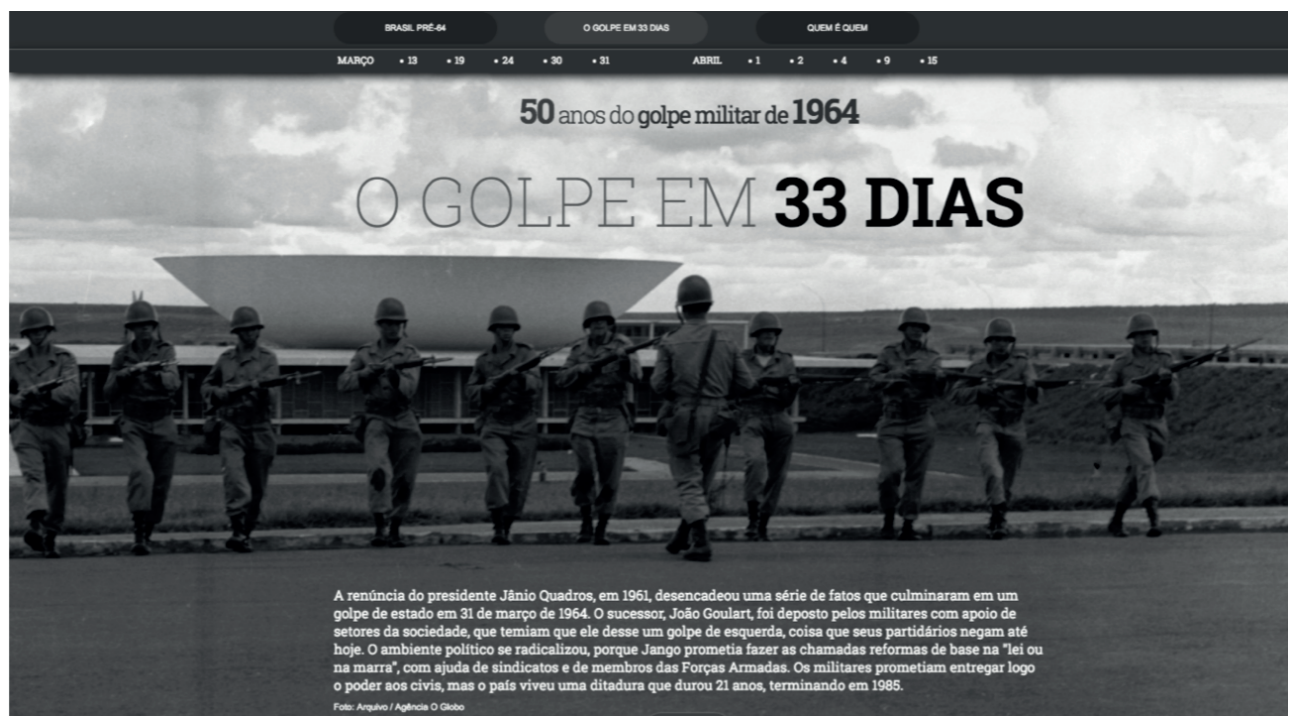

Fonte: G1. 
Aqui, contudo, não foram utilizadas memórias individuais para isso - uma vez que elas não apareceram de forma pungente, a exceção das citações em destaque uma vez “a cada dia” da parte principal, em “O golpe em 33 dias”. Por conseguinte, essa é a vertente dos próprios produtores do especial. Ainda assim, a ênfase da produção foi nos personagens envolvidos com os acontecimentos, isto é, nas pessoas que apoiaram ou combateram o golpe e a ditadura dos militares (ver Figura 5). Isso aparece em todas as três grandes partes: em “Brasil pré-64”, com ênfase em Jânio e Jango; em “O golpe em 33 dias”, com destaque em todos os dias para “Envolvidos” e “Quem apoiou”; e em “Quem é quem”, com a explicitação de “pró-Jango” e “pró-golpe” ligados a Forças Armadas, Governo, Partidos, Igreja, EUA, Movimentos, entidades e sindicatos.

Figura 5 - Comício das Reformas tem áudio histórico, citação e lista de apoiadores e envolvidos

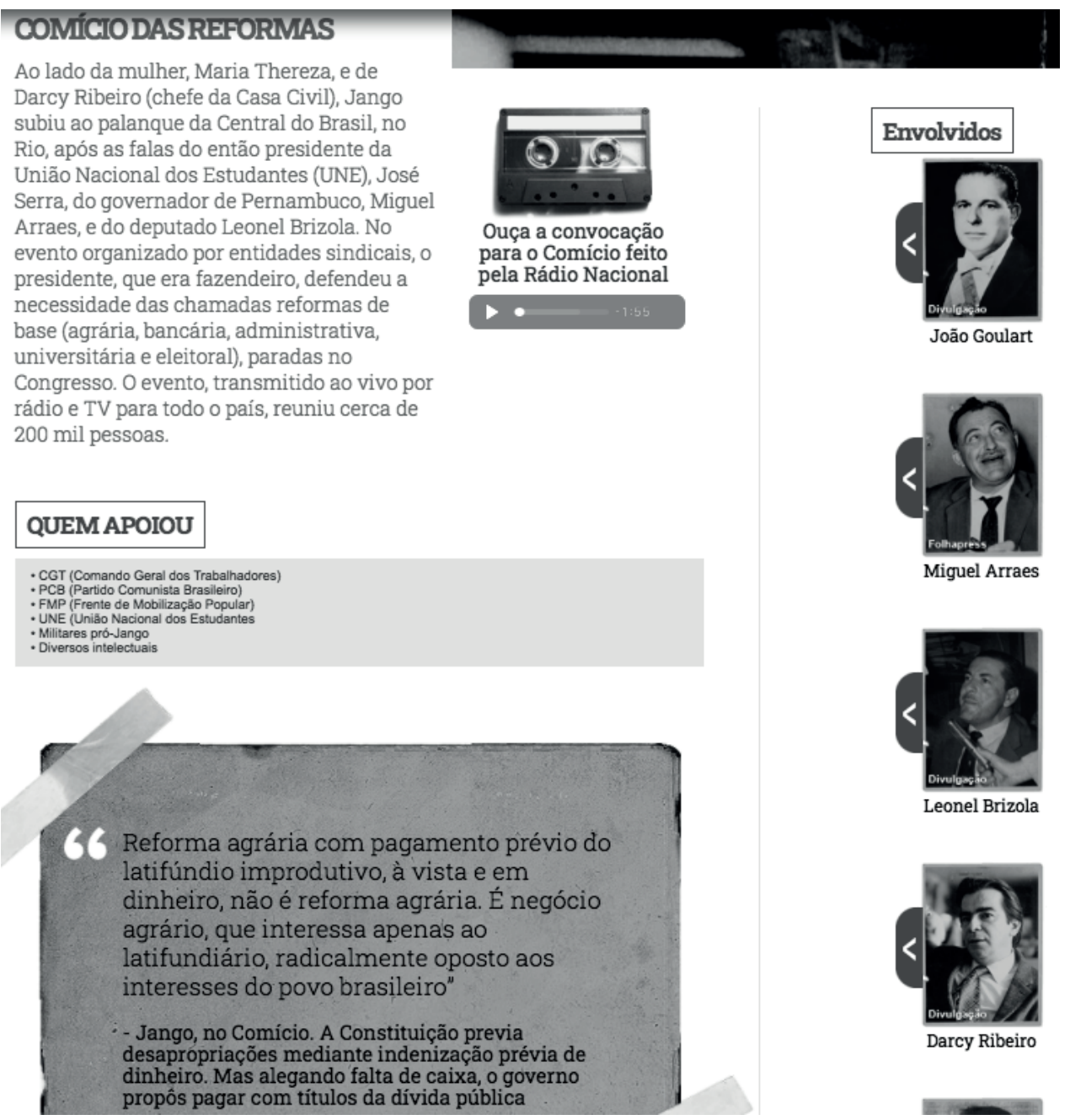

Fonte: G1. 
A pouca utilização de citações se alia a uma estrutura narrativa cronológica, diferente do paradigma do jornalismo vigente, que preza por uma hierarquia a partir da lógica da pirâmide invertida e um número extenso de citação das fontes entrevistadas. Como não segue essa lógica, o tom do texto passa a ser mais histórico e didático, com as fontes e referências observadas apenas na parte final do especial - não no corpo do texto, como nas reportagens e demais produções jornalísticas tradicionais, a exceção, no especial, das dez citações em destaque. As informações foram obtidas em três livros, escritos por Antonio Lavareda, Argelina Figueiredo e Luiz Antônio Dias, além de documentos do Arquivo Nacional e do Centro de Pesquisa e Documentação de História Contemporânea do Brasil (CPDOC) da Fundação Getúlio Vargas.

Os jornais são fontes históricas fundamentais nesta narrativa multimídia, especialmente na seção "Nas bancas de jornal” (ver Figura 6), em que são digitalizadas as capas de quatro dos principais jornais impressos do período da ditadura militar: como Correio de Manhã, Folha de S.Paulo, Jornal do Brasil e O Globo. A partir das dez datas colocadas no especial, com algo relevante relacionado ao golpe e aos dias iniciais da ditadura, era divulgada a capa de alguns desses veículos, demonstrando como os acontecimentos foram publicados e reverberaram no dia subsequente pela mídia da época. O jornalismo é considerado o primeiro rascunho da história e serve como fonte para os historiadores (PALACIOS, 2003, 2009, 2014, ZELIZER, 2008, FERREIRA; GOMES, 2014).

Figura 6 - Capas históricas dos jornais no dia seguinte à oficialização do golpe

\section{Nas bancas de jomal}

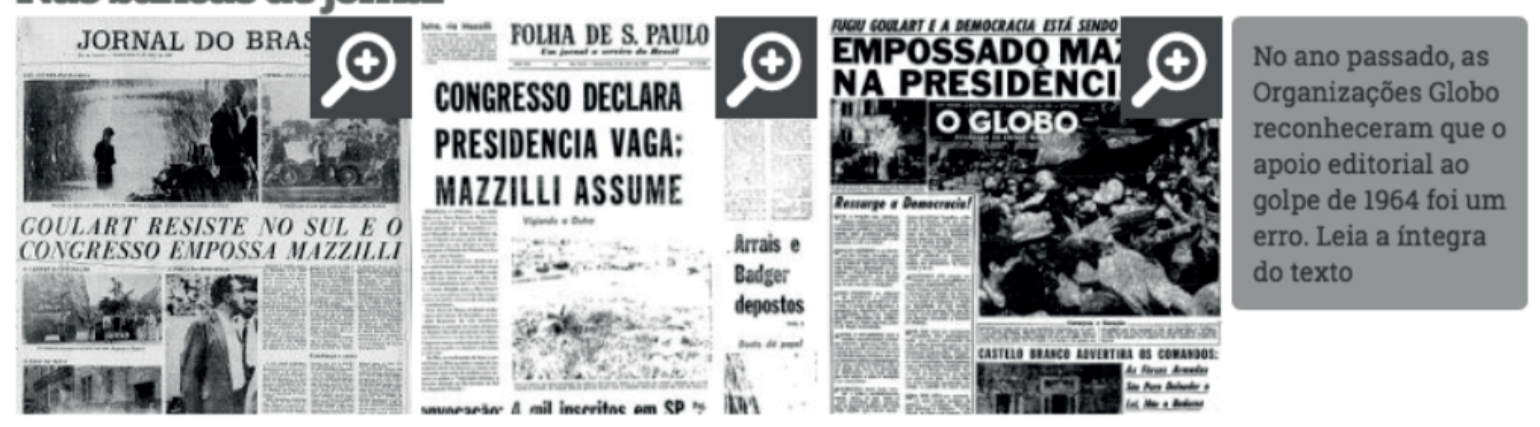

Fonte: G1.

As mais de 70 imagens históricas, ainda que a maioria seja de personagens envolvidos pró ou contra o golpe e a ditadura - uma vez que esta é a ênfase dessa narrativa multimídia -, são advindas em sua maioria - praticamente 70\% - dos grandes grupos midiáticos, com 
16 do Grupo Globo, 17 do Grupo Estado e 14 do Grupo Folha. Ainda assim, 18 são imagens históricas de divulgação dos personagens. Os três áudios são históricos: convocação para “Comício das Reformas” com João Goulart e apelo de Rubens Paiva para se defender Jango - ambos da Rádio Nacional - e declaração de Auro de Moura Andrade de vacância da presidência. Os quatro vídeos também são históricos, mas trazem a mesma perspectiva: posse de Castello Branco e “propaganda feita pelos militares”; logo, não são reportagens de telejornais, mas produções semelhantes àquelas realizadas por assessorias, ainda que com caráter mais persuasivo.

Os seis gráficos que aparecem em "Brasil pré-64” são simples, todos de barra ou de pizza, e tendo como fonte as pesquisas Ibope ou um dos três livros supracitados. As memórias aparecem também em formato explícito textualmente, sobretudo com citações diretas destacadas dos “Envolvidos” na seção "O golpe em 33 dias”. No total, 9 dos 10 dias enfatizados possuem destaques memoriais em texto, retirado do próprio acontecimento registrado em áudio ou vídeo, de documento oficial ou mesmo de matéria jornalística, como ocorreu, por exemplo, nos dias 19 e 30 de março - respectivamente, de Auro de Moura Andrade, na Folha de S.Paulo em 20 de março de 1964, e de João Goulart, no Jornal do Brasil em 31 de março de 1964, - e 4 de abril - de Maria Thereza Cruz, viúva de Jango, no Zero Hora em 2013.

\section{Portal iG - Último Segundo}

O especial sobre os "50 anos do golpe” destrincha “a ação militar que mergulhou o País em 21 anos de ditadura”. Já na abertura, Jango "se viu isolado” diante dos "golpistas” e das suas "tropas” que partiam de Minas Gerais com o apoio dos Estados Unidos através da “Operação Brother Sam”. O título e subtítulo do especial no portal iG, através do seu site de notícias Último Segundo, demonstram um enquadramento com carga negativa sobre o acontecimento em seu cinquentenário, ao utilizar palavras como golpe e ditadura. O título e subtítulo já apontam para a perspectiva negativa que as produções pregam do "golpe” e da “ditadura”, inclusive, com aquela palavra sendo o link de acesso para o especial (ver Figura 7). Aqui, não há indulgência ou compreensão com a visão dos militares ou com memórias dos seus apoiadores, uma vez que elas não aparecem. Como explicado anteriormente, essa ideia vai ao encontro da concepção de Rollemberg (2006), para quem a esquerda venceu a batalha das narrativas das memórias. A partir do primeiro de abril - o segundo abordado no especial -, o posicionamento fica ainda mais evidente ao se narrar a perseguição ao presidente João Goulart. 
Figura 7 - Especial enfatiza vínculo dos EUA com o golpe

\section{0 anos do golpe: a ação militar que mergulhou o País em 21 anos de ditadura}

Por IG S\$o Paulo | 29/03/2014 $12: 00$

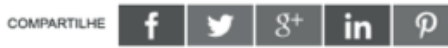

Em 31 de março de 1964, tropas partiram de Minas em direção ao Rio para depor Jango, que se viu isolado. Golpistas tinham ainda ao seu lado os Estados Unidos, com a Operação Brother Sam

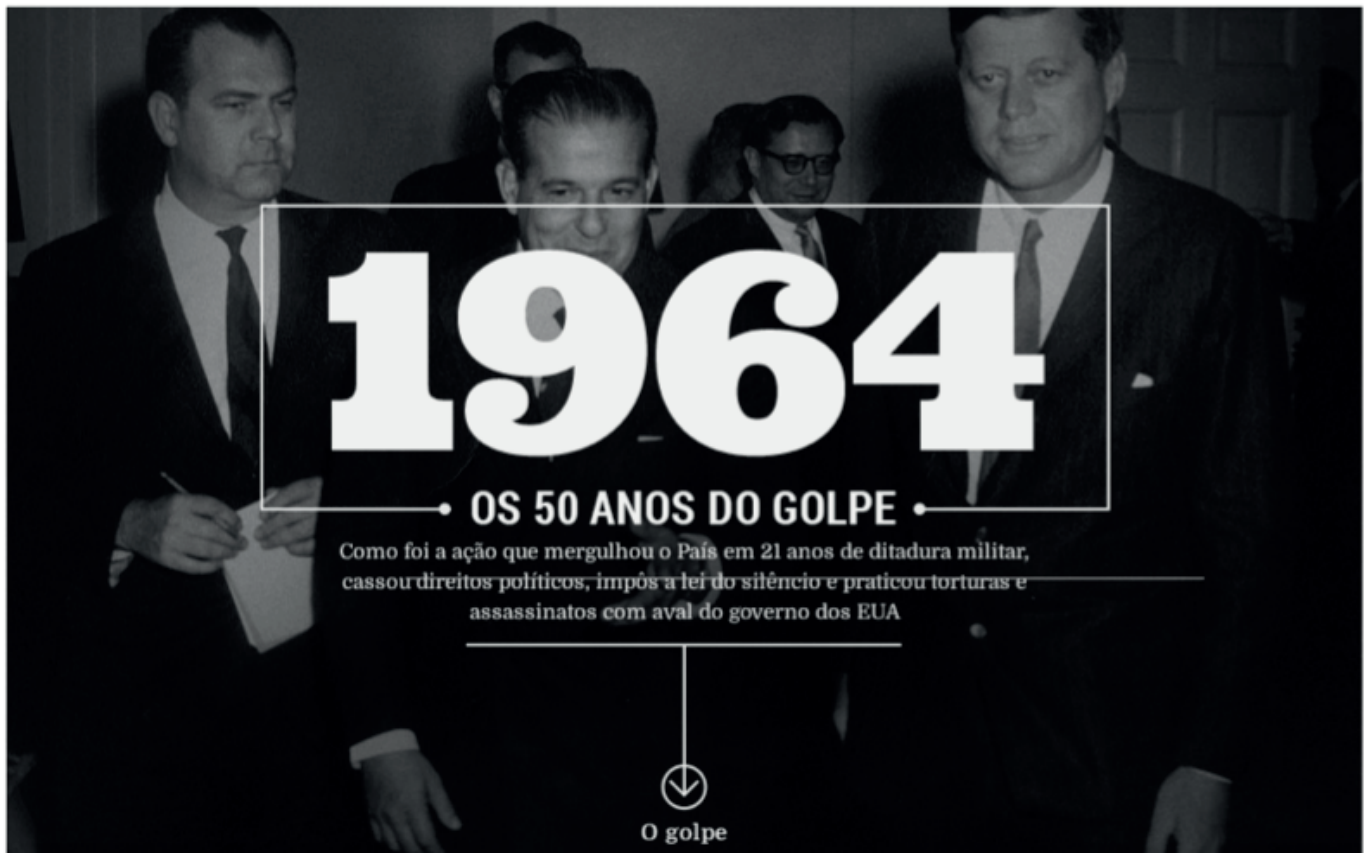

Fonte: Último Segundo.

A ênfase da produção do Último Segundo está na relação estadunidense com o golpe e a ditadura, uma vez que os militares tinham o "aval do governo dos EUA". Isso não fica evidente somente na seção “Operação BROTHER Sam” - sobre a preparação e o apoio militar estadunidense para instalação e manutenção do regime autoritário militar no Brasil -, mas desde a abertura do especial, com parte do subtítulo que explicita: “Golpistas tinham ainda ao seu lado os Estados Unidos, com a Operação Brother Sam”. A intenção dos presidentes Kennedy e Johnson eram "garantir a vitória dos golpistas”. Como já mencionado, os governantes dos EUA contribuíram financeiramente para que os oponentes do presidente fizessem campanha no Congresso Nacional. 
O especial não possui uma narrativa semelhante àquelas das produções jornalísticas tradicionais, com uma hierarquia textual definida a partir da pirâmide invertida com citação direta e indireta de fontes (ver Figura 8). Ao contrário, existe uma estrutura mais histórica e didática, com uma narrativa cronológica e nenhuma citação, a exceção, apenas, de um áudio histórico de Moura Andrade sobre a posse do presidente interino Ranieri Mazzilli, após declarar vaga a presidência. Além de não encontrarmos citações, também não existe a identificação de referências em nenhuma parte da produção.

Figura 8 - Parte do primeiro dia apresenta movimentação das tropas militares em mapa

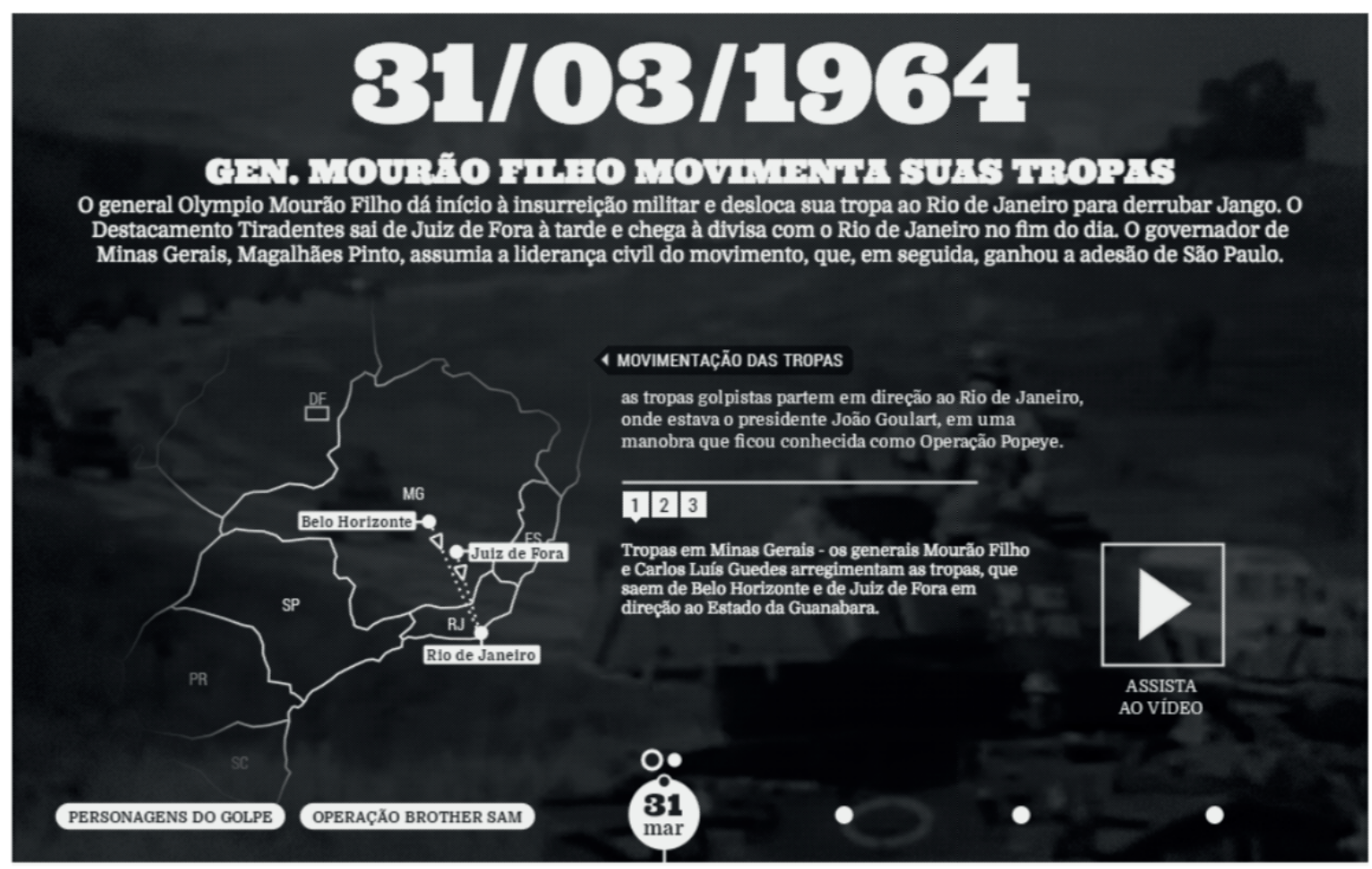

Fonte: Último Segundo.

Dos formatos midiáticos do especial, apenas um possui a fonte explícita, que é o único vídeo disponibilizado na primeira data: 31 de março. A filmagem da TV Câmara traz um tom pesaroso ao informar que neste dia as tropas militares de Minas Gerais seguiram para o Rio de Janeiro e depois para o presidente João Goulart. No total, são 18 imagens históricas, das quais 12 são fotos oficiais dos "Personagens do golpe”. As outras seis, por outro lado, estão na seção “Operação BROTHER SAM” e em cada segmento das datas, uma sendo a capa distorcida de um jornal, possível de identificar apenas a informação sobre a posse de Ranieri Mazzilli, após a vacância de Jango. 
Os infográficos aparecem em forma de mapa, nas três primeiras datas e suas subdivisões, através do caminho percorrido pelas tropas dos militares e de João Goulart. Na seção dedicada aos EUA, existem mais dois: um mapa com o caminho que seguiriam as tropas estadunidenses, em caso de resistência ao golpe, e outro que detalha as armas e o exército dos EUA. Cabe reiterar a relevância dada ao papel estadunidense no golpe e na ditadura com texto no subtítulo e imagem de abertura do especial, além de uma seção específica com mais uma foto histórica e dois infográficos, relevantes, sobretudo, devido ao desenvolvimento de poucos recursos multimídias no especial.

\section{Considerações finais}

Os especiais - com praticamente todos em formato de narrativa multimídia, a exceção de $O$ Estado de S. Paulo - concebem o "golpe” e, por consequente, a "ditadura militar” como algo negativo e pernicioso para a história do país, nos títulos e nas primeiras linhas, apresentando essas expressões que carregam uma concepção e uma interpretação desses eventos. Eles apresentam um período de exceção em que os direitos foram cerceados com arbítrio e a prática de crimes cometidos com apoio e conivência do estado através dos seus agentes armados, como assassinatos, cassações, desaparecimentos, prisões, sequestros e torturas.

O Último Segundo não apresenta nenhum aspecto positivo ou mesmo uma justificativa que se coadune com a perspectiva dos golpistas para a deposição ilegal do presidente João Goulart; ao contrário, à medida que os dias passam, o posicionamento fica mais evidente e direto, com a palavra "golpe" sendo a porta de entrada para a sua produção. A Folha de S.Paulo também segue essa visão explícita, apresentando raríssimas partes condescendentes com a perspectiva dos militares. Elas estavam restritas, sobretudo, às duas últimas seções de textos opinativos ("E se...” e "Artigos”) e aos depoimentos dos militares entrevistados. Mesmo assim, as memórias dos apoiadores do golpe aparecem em uma menor escala - em $30 \%$ dos vídeos - em comparação às recordações daqueles que se opunham à deposição de Jango - em 70\% das entrevistas; ainda assim, aqueles depoimentos parecem não conformar o discurso do veículo, como se pretendessem apenas mostrar que existem pensamentos/ posicionamentos distintos, mas o leitor deveria apreender a história que eles narram, sob aquela perspectiva.

Mesmo que $O$ Estado de S. Paulo e o G1 tenham realizado críticas semelhantes àquelas dos outros dois especiais, não se pode deixar de apontar certa complacência com os militares e os seus apoiadores. Em algumas ocasiões, o jornal paulista fala de Jango e Brizola como “perigosos" porque poderiam implementar uma ditadura comunista, perspectiva próxima a dos golpistas na época, inclusive, a do próprio Grupo Estado. Essa contemporização com o golpe pode ser explicada porque as produções prezavam, normalmente, pela apresentação estrita da visão dos entrevistados ou dos autores dos textos, que se assemelhavam aos artigos 
de opinião; todos, contudo, sem uma confrontação direta de tais visões - fossem elas a favor ou contra a deposição.

O G1 foi indulgente em diversas ocasiões com os militares, como quando falam da posse de Jango em 1961 e desconsideram as pressões contra as forças golpistas já naquela ocasião, isto é, como se os militares, pensando na harmonia do país e de maneira espontânea, tivessem garantido a posse do então vice-presidente. Essa indulgência, na verdade, transparece nos dois veículos quando acusam João Goulart de esquerdista e comunista para justificar o rompimento em 31 março de 1964, sobretudo através de entrevistados. Jango teria radicalizado ao tentar impor as "reformas de base na 'lei ou na marra”, adequando-se ao que o próprio Grupo Globo defendeu na época.

O G1 trata de maneira histórica apenas o golpe e os acontecimentos em torno dele, enquanto a Folha de S.Paulo chega até os dias atuais, passando pela ditadura até os movimentos para reparação histórica iniciada nos anos de 1990 com Comissão Especial de Mortos e Desaparecidos e a Comissão Nacional da Verdade (2012-2014). O Estado de S. Paulo e o Último Segundo enfatizaram o papel dos Estados Unidos no apoio ao golpe, algo evidenciado em toda a produção dos dois veículos ao citarem e detalharem a Operação Brother Sam. O veículo jornalístico do portal iG apresenta essa vinculação desde o subtítulo, na abertura do especial, até a sua seção específica.

O texto jornalístico padrão possui hierarquia de estrutura em algum nível piramidal, seja invertida, deitada ou em fluxos. Dos especiais analisados, apenas O Estado de S. Paulo não trabalhou com uma narrativa multimídia, possuindo, portanto, uma hierarquia aos moldes desse jornalismo tradicional - com reportagens e artigos de opinião -, a exceção da sua primeira produção, praticamente sem citação e escrito de forma histórica e didática, como se fosse a verdade a ser apreendida. Os outros três veículos, contudo, prezaram pela ordem cronológica dos acontecimentos, seguindo datas preponderantes. A Folha de S.Paulo não fugiu da cronologia, mesmo que tenha expandido as produções para além do golpe, chegando a falar da ditadura e ainda dos resquícios após seu fim até os dias atuais. As citações nos três jornais que produziram narrativa multimídia são praticamente nulas, com exceção dos depoimentos em vídeo neste veículo paulista - mais próximo de citação -, ainda que não tenham influenciado na narrativa do especial, aparecendo de maneira mais periférica e ilustrativa.

O tom histórico e didático domina as narrativas multimídias, com as fontes e referências observadas apenas na parte final do especial, não no corpo do texto, como é comum nas produções jornalísticas. Os jornais fizeram um compêndio das leituras e apresentaram a sua perspectiva dos fatos, a forma como interpretaram o acontecimento em 1964, todavia, sem muitas citações diretas e indiretas. As memórias coletivas em livros e obras clássicas sobre o golpe e a ditadura prevalecem, com as memórias individuais ficando mais relegadas ao que não era central na narrativa e no discurso do veículo, aparecendo para trazer a visão de um indivíduo, com exceção do Estadão. 
A Folha de S.Paulo, o portal G1 e o Último Segundo demarcaram bem o seu posicionamento, com essas memórias pessoais aparecendo de modo periférico, mesmo que se adequassem à perspectiva do veículo. A mensagem é clara, corroborando ou não como interpretam o acontecimento: o importante é a narrativa central do veículo, não as recordações individuais. O Último Segundo não realiza nenhuma citação ou mesmo coloca referências ao final; a Folha de S.Paulo traz memórias individuais, porém, as memórias coletivas predominam, com livros e documentos históricos disponibilizados na seção "Fontes e Referências”. No G1, as memórias individuais aparecem somente nas poucas citações com a marca gráfica de destaque, com todas as informações da narrativa principal partindo de apenas três livros. Mesmo que a ênfase do especial esteja nos personagens envolvidos com o golpe e a ditadura, as memórias são coletivas, não individuais. As informações partem de documentos históricos e livros. Por outro lado, O Estado de S. Paulo é o único a seguir uma estrutura jornalística padrão, citando diversas vezes suas fontes como base para a construção da narrativa jornalística, desde pesquisadores, estudiosos e políticos opositores até exmilitares. A memória individual aparece mais forte como legitimadora do que a coletiva.

O Último Segundo foi o único que não se utilizou de jornais antigos, do período do golpe, como fontes para o seu especial. O fato de ser o único que não é de um grupo midiático histórico não impediria esse tipo de utilização, uma vez que o G1, por exemplo, utilizou-se mais de jornais de fora do seu grupo. A Folha de S.Paulo citou suas produções anteriores apenas em dois artigos de opinião, porém, praticamente não disponibilizou nenhum conteúdo digitalizado, com exceção de uma reportagem em vídeo da TV Cultura. $O$ Estado de S. Paulo produziu um infográfico completamente autorreferencial, fundamentado somente nas matérias publicadas no seu jornal impresso, a fim de fazer uma reconstituição do golpe e da ditadura militar, de 1960 até 1990. É um tipo de (auto)legitimação de maneira endógena. O veículo do Grupo Globo, por sua vez, foi o que melhor trabalhou esse tipo de memória, com os jornais aparecendo como fontes históricas em toda a narrativa multimídia, com a seção "Nas bancas de jornal".

\section{Referências}

BARBOSA, S.; NORMANDE, N.; ALMEIDA, Y. Produção horizontal e narrativas verticais: novos padrões para as narrativas jornalísticas. In: XXIII ENCONTRO ANUAL DA ASSOCIAÇÃO NACIONAL DOS PROGRAMAS DE PÓS-GRADUAÇÃO EM COMUNICAÇÃO (COMPÓS), 2014, Belém. Anais.... Belém: UFPA, 2014, p. 1-19.

BLANCHARD, P.; VEYRAT-MASSON, I. Introduction. Hermès, CNRS, France, n. 52, v. 3, 2008a, p. 13-22.

BLANCHARD, P.; VEYRAT-MASSON, I. Les guerres de mémoires: La France et son histoire, enjeux politiques, controverses historiques, stratégies médiatiques. Paris: La Découverte, 2008b.

BOURDON, J. Media remembering: the contributions of life-story methodology to memory/media research. In: NEIGER, M.; MEYERS, O.; ZANDBERG, E. (Ed.). On media memory: collective memory in a new media age. United Kingdom: Palgrave Macmillan, 2011, p. 62-73. 
CANAVILHAS, J. Webjornalismo: da pirâmide invertida à pirâmide deitada. Biblioteca On-line de Ciências da Comunicação (BOCC), Covilhã: Universidade da Beira Interior, 2006.

CANAVILHAS, J. Hipertextualidade: novas arquiteturas noticiosas. In: CANAVILHAS, J. Webjornalismo: 7 caraterísticas que marcam a diferença. Covilhã, Portugal: Livros Labcom, 2014, p. 3-24.

CARDOSO, L. Criações da memória: defensores e críticos da Ditadura (1964-1985). Cruz das Almas: Editora da UFRB, 2012.

DELGADO, L. O governo João Goulart e o golpe de 1964: memória, história e historiografia. Tempo, Rio de Janeiro, n. 28, 2010, p. 123-143.

DIAS, A. Herzog re(a)presentado: notas sobre memória, narrativa e "acontecência”. In: XXIV ENCONTRO ANUAL DA ASSOCIAÇÃO NACIONAL DOS PROGRAMAS DE PÓS-GRADUAÇÃO EM COMUNICAÇÃO (COMPÓS), Brasília, UnB e UCB, 2015. Anais....

DIAS, A. O presente da memória. Usos do passado e as (re)construções de identidade da Folha de S. Paulo, entre o “golpe de 1964” e a “ditabranda”. Jundiaí: Paco Editorial, 2014.

FERREIRA, J. O governo Goulart e o golpe civil-militar de 1964. In: FERREIRA, J.; DELGADO, L. (Orgs.). O Brasil republicano. O tempo da experiência democrática: da democratização de 1945 ao golpe civilmilitar de 1964. Rio de Janeiro: Civilização Brasileira, 2003, p. 343-425.

FERREIRA, J.; GOMES, A. 1964. Rio de Janeiro: Civilização brasileira, 2014.

FICO, C. Versões e controvérsias sobre 1964 e a ditadura militar. Revista Brasileira de História. São Paulo, v. 24, n. 47,2004 , p. 29-60.

FICO, C. O regime militar no Brasil (1964/1985). São Paulo: Saraiva, 2005.

FRANCO, G. Como escrever para Web. EUA, Knight Center for Journalism in the Americas, 2008.

HOSKINS, A. Digital network memory. In: ERLL, A.; RIGNEY, A. (Ed.). Mediation, remediation, and the dynamics of cultural memory. Berlin and New York: Walter de Gruyter, 2009, p. 91-106.

HOSKINS, A. Anachronisms of media, anachronisms of memory: from collective memory to a new memory ecology. In: NEIGER, M.; MEYERS, O.; ZANDBERG, E. (Ed.). On media memory: collective memory in a new media age. United Kingdom: Palgrave Macmillan, 2011a, p. 278-288.

HOSKINS, A. From collective memory to memory systems. Memory Studies, v. 4, n. 2, 2011b, p. 131-133. KOSHIYAMA, A. O jornalismo e o golpe de 1964. Revista Brasileira de Ciências da Comunicação (Intercom), v. 11, n. 59, 1988, p. 65-71.

LE GOFF, J. História e memória. 7ª edição revista. São Paulo: Unicamp, 2013 [1988].

LINDENBERG, D. Guerres de mémoire en France. Vingtième Siècle, Revue d'histoire, n. 42, avril-juin, 1994, p. 77-96.

MACHADO, E. O jornal digital como epicentro das redes de circulação de notícias. In: XXIV CONGRESSO BRASILEIRO DE CIÊNCIAS DA COMUNICAÇÃO (INTERCOM), 2001, Campo Grande. Anais.... Campo Grande, 2001, p. 1-15.

MACHADO. J. 1964: golpe midiático-civil-militar. Porto Alegre: Sulina, 2014.

NEIGER, M.; MEYERS, O.; ZANDBERG, E. (Ed.). On media memory: collective memory in a new media age. United Kingdom: Palgrave Macmillan, 2011. 
NORMANDE, N. Padrões de narrativas multimídias: análise de produções premiadas e casos ilustrativos. Dissertação (Mestrado em Comunicação e Cultura Contemporâneas). Universidade Federal da Bahia, Salvador, 2014.

NUNES, M. A memória na mídia: a evolução dos memes de afeto. São Paulo: Annablume, 2001.

PALACIOS, M. Jornalismo online, informação e memória: apontamentos para debate. In: WORKSHOP DE JORNALISMO ONLINE, 2002, Covilhã. Anais.... Covilhã, 2002, p. 1-12.

PALACIOS, M. Ruptura, continuidade e potencialização no jornalismo online: o lugar da memória. In: MACHADO, Elias; PALACIOS, Marcos M. (Org.). Modelos do Jornalismo Digital. Salvador: Editora Calandra, 2003, p. 1-17.

PALACIOS, M. A memória como critério de aferição de qualidade no ciberjornalismo: alguns apontamentos. Revista Famecos, v. 37, p. 91-100, 2008.

PALACIOS, M. Convergência e memória: jornalismo, contexto e história. In: I CONGRESO DE CIBERPERIODISMO Y WEB 2.0, 2009, Bilbao. Anais.... Bilbao: 2009, p. 1-14.

PALACIOS, M. Memória: jornalismo, memória e história na era digital. In: CANAVILHAS, J. Webjornalismo: 7 caraterísticas que marcam a diferença. Covilhã, Portugal: Livros Labcom, 2014, p. 89-110.

READING, A. Memory and digital media: six dynamics of the globital memory field. In: NEIGER, M.; MEYERS, O.; ZANDBERG, E. (Ed.). On media memory: collective memory in a new media age. United Kingdom: Palgrave Macmillan, 2011, 241-252.

REIS, D. A ditadura faz cinquenta anos: história e cultura política nacional-estatista. In: REIS, D.; RIDENTI, M.; MOTTA, R. A ditadura que mudou o Brasil. 50 anos do golpe de 1964. Rio de Janeiro: Zahar, 2014, p. 7-17.

REIS, D.; RIDENTI, M.; MOTTA, R. A ditadura que mudou o Brasil. 50 anos do golpe de 1964. Rio de Janeiro: Zahar, 2014.

RIDENTI, M. As oposições à ditadura: resistência e integração. In: REIS, D.; RIDENTI, M.; MOTTA, R. A ditadura que mudou o Brasil. 50 anos do golpe de 1964. Rio de Janeiro: Zahar, 2014, p. 18-28.

ROEDIGER III, H.; WERTSCH, J. Creating a new discipline of memory studies. Memory Studies, v. 1, n. 1, 2008, p. 9-22.

ROLLEMBERG, D. Esquecimento das memórias. In: MARTINS FILHO, J. (Org.). O golpe de 1964 e o regime militar. São Carlos: UFSCar, 2006, p. 81-91.

SÁ, A. Arquivos dos media e preservação da memória. Processos e estratégias do caso português na era digital. Tese (Doutorado em Comunicação). Universidade do Minho, Portugal, 2011.

SCHUDSON, M. Descobrindo a notícia: uma história social dos jornais nos Estados Unidos. Petrópolis: Vozes, 2010.

SILVA, H. "Rememoração”/comemoração: as utilizações sociais da memória. Revista Brasileira de História, São Paulo, v. 22, n. 44, 2002, p. 425-438.

STORA, B. La guerre des mémoires. La Franceface à son passé colonial (Entretien avec Thierry Leclère). Paris, L’Aube, 2007.

ZELIZER, B. Why memory's work on journalism does not reflect journalism's work on memory. Memory Studies, v. 1, n. 1, 2008, p. 79-87. 


\section{Allysson Viana Martins}

Professor de Jornalismo e coordenador do MíDI - Grupo de Pesquisa em Mídias Digitais e Internet na Universidade Federal de Rondônia (UNIR). Doutor e Mestre em Comunicação e Cultura Contemporâneas pela Universidade Federal da Bahia (UFBA), com estágio doutoral no Laboratoire Communication et Politique du Centre National de la Recherche Scientifique (CNRS). É autor do livro “Jornalismo e Guerras de Memórias nos 50 Anos do Golpe de 1964” e do e-books "Crossmídia e Transmídia no Jornalismo” (2011) e “Afrodite no Ciberespaço” (2010), este uma coorganização. Já recebeu prêmios no EXPOCOM e no PIBIC, como estudante e como professor orientador. E-mail: allyssonviana@unir.br.

Recebido em: 08.03.2019

Aprovado em: 26.08.2020 